\title{
Towards Establishing the Hierarchical Inter- Relationships amongst the Governing Criteria behind Family Businesses
}

\author{
Remica Aggarwal \\ Recventures Education Services \\ Private Limited \\ Delhi, India
}

\author{
Viraj Voditel \\ Techture Structures Private \\ Limited \\ Nagpur, India
}

\author{
Lakshay Aggarwal \\ Recventures Education Services \\ Private Limited \\ Delhi, India
}

\begin{abstract}
Present paper tries to explore the various criteria for the success and failure of family businesses in world. It thereafter, tries to study the inter-relationships amongst them using ISM methodology.
\end{abstract}

\section{Keywords}

Family businesses; ISM methodology; Entrepreneurship; familial entrepreneurship

\section{INTRODUCTION}

Founded on the joint family principle of ownership and management, contribution of family businesses has been marked by the entrepreneurial capitalism [1]. entrepreneurship is a determining factor of economic development [2]. entrepreneurship not only contributes to the economic and social growth of a nation, but also stimulates the development of knowledge and technological change [3], competitiveness and innovation [4]. Entrepreneurial intention is closely linked to business world. Present work tries to explore the various criteria behind the success and failure of family businesses. It thereafter, tries to study the interrelationships amongst them using ISM methodology. The paper is arranged as follows: Section 2 studies the various criteria. Section 3 study the ISM methodology. Section 4 studies the case example. Section 5 presents the conclusions.

\section{LITERATURE REVIEW ON SUCCESS FACTORS AND CHALLENGES TO FAMILY BUSINESSES}

\subsection{Literature review on success factors to family businesses}

2.1.1 High levels of self-efficacy [HLSE] : Specifically, this factor is studied by [5],[6] to perform the entrepreneurial activities.

2.1.2 Risk taking capability [RTC] : Risk propensity or risk taking capabilities are studied by [7].

2.1.3 Tolerance to ambiguity and uncertainty [TAU] : this success factor is largely studied by[7], metacognitive abilities and individual abilities $[8,9]$ as well as creativity [10].

2.1.4 Role of culture [RoC] : [5] studied the role of culture as psychological, acting at the individual level.

2.1.5 Culture with respect to Business contexts [CBC] : This factor is studied by researchers such as [11]; in context of Islamic [12]; Mohd Rhouse et al., 2016), and Middle Eastern cultures [15]; [13],[14].

2.1.6 Individual choice [IC] : According to the researchers such as [16],[ 17],[18], possibility of being able to inherit the family business does not make it a desirable choice.

2.1.7 Strength of family expectations [SFE] : The performance of those who enter the family business is better when perceived family responsibility as strong, this result highlights the strength of family expectations in positively influencing members' performance [[19]

2.1.8 Involvement of family [IoF] : Based on data from 228 entrepreneurs, [20] found that the active involvement of the family creates a common destiny among members that favors resilience for an entrepreneur, compared to the owners of non-family businesses.

2.1.9 Intention of members [IoM]: factors that influence the intentions of the members of the next generation to undertake an entrepreneurial career also considers the behaviors of their parents [21] and their children [18].

2.1.10 Parental role models [PRM] : Parental role models increased the likelihood of individuals becoming self-employed [22]. Urbano et al. (2011), instead, established that individuals with the same ethnicity can act as a model, encouraging other individuals in the community to create new businesses. Pablo-Lerchundi et al. (2015) showed that the profession carried out by parents influences the entrepreneurial intentions of students.

2.1.11 Professional role models [PRRM] : [23] Laviolette et al. (2012), [24],[25],[26][18], [29] found that role models has positive influence provided that such models are positively perceived by individuals.

2.1.12 Structural and emotional family support [SFS] : from [25], [28], it emerged that university support, structural support and emotional support of the family are important factors that influence the entrepreneurial intention of students.

2.1.13 Visibility and exposure [V\&E] : The perks of being in a family business are the visibility and exposure that one gets into every aspect of running the company. Another benefit is the ease in taking risky decisions.

2.1.14 Known for ethics [KFE] : Most of the family run businesses are known for the ethics that they follow and 
it naturally creates a legacy for the coming generation to continue.

\subsection{Key challenges to family businesses [30-33]}

2.2.1 Miscellaneous issues [MI] : The key areas where family run firms continue to face unique challenges are Family Wealth Management, Managing Family Relationships and Professionalization.

2.2.2 Communication problems [CP] : Relationship between parents and children or among siblings has a tendency to deteriorate due to communication problems. Family problems may spill over into the workplace. There may be times when the interests of a family member conflict with the interests of the business.

2.2.3 In ability to adapt to increasing competition [IIC] : One of the popular myths about family businesses is that they are unable to adapt easily to increasing competition and technological progress. But as the new generation steps in, the family businesses subsequently have the advantage of entrepreneurial spirit and flexibility.

2.2.4 managing growth [MG] : First and second generation of family owners in India now face a vastly different business landscape to when they first started but they are also taking centre stage in the global economy, at the heart of a region that has tremendous room for development and growth.

2.2.5 Professionalising the business and the family [PB\&F] : As Indian family businesses continue to establish greater presence globally and grow to a certain size, they also face more intense competitive pressures, rising costs and the impact of global mega trends. Yet for any family business to take advantage of the opportunity to grow in today's globalized world, the challenge is to identify ways in which to do that as effectively as they can.

2.2.6 Acquiring talent and skills [ ATS] : Attracting and retaining talent continues to weigh on the minds of family owners as they compete for the right skills and a strong talent pool needed to drive their business.

2.2.7 Managing succession/Grooming the next generation of business leaders [ MS] : As Indian family businesses are generally facing only their first or second transition, the process may be new to them. And for those taking over the family business, expectations and plans of the succession process can pose some worry how will their parents adapt, how they will measure up and overall being able to manage the process successfully by ensuring their parents still feel involved and able to contribute.

2.2.8 Managing conflicts [MC]: Between generations, there can be gaps in communication and credibility. The collision of expectations and the lack of communication can be emotionally-charged but more importantly, harm relationships between key family members which eventually affects the business.

2.2.9 Non participative family members [NPFM] : Every family-owned business have some members who are actively involved in the business but there are stake holders who are not actively part of the business like mother, sisters, uncles, aunts, in-laws etc. These people are interested only in dividends and earnings and not in the growth of the business they are unable to comprehend the problems of operating a business.

2.2.10 Family emotions [Fe] : Emotional outbursts are many in family-owned businesses and the quarrels and ill feelings of relatives have a way of spreading out to include non-family employees. It is believed by many business thinkers that emotions are very essential to operate a business. But these emotions and passion have to be related to business.

2.2.11 Human Resource [HR]: In family business the family has to be always accommodated first with jobs. In some cases, family members and relatives can demoralize the organization by their dealings with other employees. Untalented family members should be put in jobs where they will have minimum contact with other employees, out of the mainstream of decision making.

2.2.12 Retaining non family professionals [RNFP]: It is a big challenge in some family-owned companies to retain non family professionals. Family-owned businesses have not been able to keep the morale of their non-family professionals very high this has affected their growth aspects

2.2.13 Fair to all approach [FTA]: Family in India have always prided themselves in being fair to all in the family. Open decision-making and procedures that ensure fairness in evaluating and rewarding both family and non-family employees are essential tools in avoiding tensions and raising the reputation of company.

2.2.14 Succession Planning [SP] : Succession planning is almost absent in family-owned business in India even in the biggest private sector company in India like Reliance. The split in the company was not amicable and resulted in a loss to the investors wealth and Reliance slipped from its position in the Forbes List.

\section{INTERPRETIVE STRUCTURAL MODELLING METHODOLOGY}

Suggested by Warfield [34], ISM works with the following steps: It starts with identifying the relevant elements and pairwise establishing the contextual relationship amongst them. Thereafter, a structural self-interaction matrix (SSIM) may be developed between two variables i.e. $i$ and $j$ establishing a "Lead to" relationship between criteria. Four symbols viz. V, $\mathrm{A}, \mathrm{X} \& \mathrm{O}$ are used for establishing the relationships. After that, a level partition matrix can be obtained based on establishing the precedence relationships and arranging the elements in a topological order. A Mic-Mac analysis is performed categorizing the variables in to autonomous, dependent, driver and linkage category. Finally, a diagraph can be obtained.

\section{CASE EXAMPLE}

14 success factors viz. High levels of self-efficacy [HLSE] ; Building of risk taking capability [BRTC]; Tolerance to ambiguity, and uncertainty [TAU]; Role of culture [RoC] ; Culture with respect to Business contexts [CBC]; Individual choice [IC]; Strength of family expectations [SFE]; Involvement of family [IoF]; Intention of members [IoM]; Parental role models [PRM]; Professional role models [PRRM] ; Structural and emotional family support [SFS] ; Visibility and exposure [V\&E] ; Known for ethics / Positive building of ethics [KFE] and 14 challenges viz. 
Miscellaneous issues [MI] ; Communication problems [CP] ; In ability to adapt to increasing competition [IIC] ; Managing growth $[\mathrm{MG}]$; Professionalising the business and the family $[\mathrm{PB} \& \mathrm{~F}] ; \quad$ Acquiring talent and skills [ATS] ; Managing succession/Grooming the next generation of business leaders [MS] ; Managing conflicts [MC]; Non participative family members [NPFM] ; Family emotions [ FE] ; Human Resource [HR]; Retaining non family professionals [RNFP]; Fair to all approach [FTA]; Succession Planning [SP] ; Leadership succession [LS] described in section 2 above have been identified through literature survey over search engines such as google scholar exploring published articles available in Research gate, academia.edu etc. These criteria are studied further for possible inter-relationships amongst them using ISM methodology below.

\subsection{Construction of Structural self- interaction Matrix (SSIM)}

This matrix gives the pair-wise relationship between two variables i.e. $i$ and $j$ based on VAXO. SSIM has been presented below in Fig 1 between the various success factors behind family businesses .

\subsection{Construction of Initial Reachability Matrix and final reachability matrix}

The SSIM has been converted in to a binary matrix called the initial reachability matrix shown in fig. 2 by substituting $\mathrm{V}, \mathrm{A}$, $\mathrm{X}, \mathrm{O}$ by 1 or 0 as per the case. After incorporating the transitivity, the final reachability matrix is shown below in the Fig 3.

\begin{tabular}{|l|l|l|l|l|l|l|l|l|l|l|l|l|l|l|l|}
\hline $\begin{array}{l}\text { S. } \\
\text { No. }\end{array}$ & Barriers & 1 & 2 & 3 & 4 & 5 & 6 & 7 & 8 & 9 & 10 & 11 & 12 & 13 & 14 \\
\hline & & HLSE & BRTC & TAU & RoC & CBC & IC & SFE & IoF & IoM & PRM & PRRM & SFS & V\&E & KFE \\
\hline 1 & HLSE & 1 & 1 & 1 & 0 & 0 & 1 & 0 & 0 & 0 & 0 & 0 & 0 & 1 & 1 \\
\hline 2 & BRTC & 0 & 1 & 1 & 0 & 0 & 0 & 0 & 0 & 0 & 0 & 0 & 0 & 0 & 0 \\
\hline 3 & TAU & 0 & 1 & 1 & 0 & 0 & 0 & 0 & 0 & 0 & 0 & 0 & 0 & 0 & 0 \\
\hline 4 & RoC & 1 & 1 & 1 & 1 & 1 & 1 & 1 & 1 & 1 & 1 & 1 & 1 & 1 & 1 \\
\hline 5 & CBC & 1 & 1 & 1 & 1 & 1 & 0 & 0 & 0 & 0 & 0 & 0 & 0 & 0 & 0 \\
\hline 6 & IC & 1 & 1 & 1 & 0 & 1 & 1 & 1 & 1 & 1 & 1 & 1 & 1 & 1 & 1 \\
\hline 7 & SFE & 1 & 1 & 1 & 0 & 1 & 1 & 1 & 1 & 1 & 1 & 1 & 1 & 1 & 1 \\
\hline 8 & IoF & 1 & 1 & 1 & 0 & 1 & 1 & 1 & 1 & 0 & 0 & 0 & 1 & 1 & 1 \\
\hline 9 & IoM & 1 & 1 & 1 & 0 & 1 & 1 & 1 & 1 & 1 & 0 & 0 & 0 & 0 & 0 \\
\hline 10 & PRM & 1 & 1 & 1 & 0 & 1 & 1 & 1 & 1 & 1 & 1 & 1 & 1 & 1 & 1 \\
\hline 11 & PRRM & 1 & 1 & 1 & 0 & 1 & 1 & 1 & 1 & 1 & 1 & 1 & 1 & 1 & 1 \\
\hline 12 & SFS & 1 & 1 & 1 & 0 & 1 & 1 & 1 & 1 & 1 & 0 & 0 & 1 & 1 & 1 \\
\hline 13 & V\&E & 0 & 1 & 1 & 0 & 1 & 1 & 1 & 1 & 1 & 0 & 0 & 0 & 1 & 0 \\
\hline 14 & KFE & 1 & 1 & 1 & 0 & 1 & 1 & 1 & 1 & 1 & 0 & 0 & 0 & 1 & 1 \\
\hline
\end{tabular}

Fig 1: SSIM matrix for pair wise relationship amongst success factors

\begin{tabular}{|l|l|l|l|l|l|l|l|l|l|l|l|l|l|l|l|l|}
\hline $\begin{array}{l}\text { S. } \\
\text { No. }\end{array}$ & Barriers & 1 & 2 & 3 & 4 & 5 & 6 & 7 & 8 & 9 & 10 & 11 & 12 & 13 & 14 & D.P \\
\hline & & HLSE & BRTC & TAU & RoC & CBC & IC & SFE & IoF & IoM & PRM & PRRM & SFS & V\&E & KFE & \\
\hline 1 & HLSE & 1 & 1 & 1 & 0 & 1 & 1 & 1 & 1 & 1 & 1 & 1 & 1 & 1 & 1 & 13 \\
\hline 2 & BRTC & 0 & 1 & 1 & 0 & 0 & 0 & 0 & 0 & 0 & 0 & 0 & 0 & 0 & 0 & 2 \\
\hline 3 & TAU & 0 & 1 & 1 & 0 & 0 & 0 & 0 & 0 & 0 & 0 & 0 & 0 & 0 & 0 & 2 \\
\hline 4 & RoC & 1 & 1 & 1 & 1 & 1 & 1 & 1 & 1 & 1 & 1 & 1 & 1 & 1 & 1 & 14 \\
\hline 5 & CBC & 1 & 1 & 1 & 1 & 1 & 1 & 1 & 1 & 1 & 1 & 1 & 1 & 1 & 1 & 14 \\
\hline 6 & IC & 1 & 1 & 1 & 0 & 1 & 1 & 1 & 1 & 1 & 1 & 1 & 1 & 1 & 1 & 13 \\
\hline 7 & SFE & 1 & 1 & 1 & 0 & 1 & 1 & 1 & 1 & 1 & 1 & 1 & 1 & 1 & 1 & 13 \\
\hline 8 & IoF & 1 & 1 & 1 & 1 & 1 & 1 & 1 & 1 & 1 & 0 & 0 & 1 & 1 & 1 & 11 \\
\hline 9 & IoM & 1 & 1 & 1 & 0 & 1 & 1 & 1 & 1 & 1 & 1 & 1 & 1 & 1 & 1 & 13 \\
\hline 10 & PRM & 1 & 1 & 1 & 0 & 1 & 1 & 1 & 1 & 1 & 1 & 1 & 1 & 1 & 1 & 13 \\
\hline 11 & PRRM & 1 & 1 & 1 & 0 & 1 & 1 & 1 & 1 & 1 & 1 & 1 & 1 & 1 & 1 & 13 \\
\hline 12 & SFS & 1 & 1 & 1 & 1 & 1 & 1 & 1 & 1 & 1 & 0 & 0 & 1 & 1 & 1 & 12 \\
\hline 13 & V\&E & 0 & 1 & 1 & 1 & 1 & 1 & 1 & 1 & 1 & 1 & 1 & 1 & 1 & 1 & 13 \\
\hline 14 & KFE & 1 & 1 & 1 & 1 & 1 & 1 & 1 & 1 & 1 & 1 & 1 & 1 & 1 & 1 & 14 \\
\hline & De.P & 11 & 14 & 1 & 6 & 1 & 1 & 1 & 1 & 12 & 1 & 1 & 1 \\
\end{tabular}

Fig 2: Initial reachability matrix 


\begin{tabular}{|l|l|l|l|l|l|l|l|l|l|l|l|l|l|l|l|}
\hline $\begin{array}{l}\text { S. } \\
\text { No. }\end{array}$ & Barriers & 1 & 2 & 3 & 4 & 5 & 6 & 7 & 8 & 9 & 10 & 11 & 12 & 13 & 14 \\
\hline & & HLSE & BRTC & TAU & RoC & CBC & IC & SFE & IoF & IoM & PRM & PRRM & SFS & V\&E & KFE \\
\hline 1 & HLSE & & V & V & A & A & X & A & A & A & A & A & A & V & X \\
\hline 2 & BRTC & & & X & A & A & A & A & A & A & A & A & A & A & A \\
\hline 3 & TAU & & & & A & A & A & A & A & A & A & A & A & A & A \\
\hline 4 & RoC & & & & & X & V & V & V & V & V & V & V & V & V \\
\hline 5 & CBC & & & & & & A & A & A & A & A & A & A & A & A \\
\hline 6 & IC & & & & & & & X & X & X & X & X & X & X & X \\
\hline 7 & SFE & & & & & & & & X & X & X & X & X & X & X \\
\hline 8 & IoF & & & & & & & & & A & A & A & X & V & V \\
\hline 9 & IoM & & & & & & & & & & A & A & A & A & A \\
\hline 10 & PRM & & & & & & & & & & & X & V & V & V \\
\hline 11 & PRRM & & & & & & & & & & & & V & V & V \\
\hline 12 & SFS & & & & & & & & & & & & & V & V \\
\hline 13 & V\&E & & & & & & & & & & & & & & A \\
\hline 14 & KFE & & & & & & & & & & & & & & \\
\hline
\end{tabular}

Fig 3 : Final reachability matrix

D.P : Driving power ; De.P : Dependence power

\subsection{Level Partition}

From the final reachability matrix, reachability and final antecedent set for each factor are found. The elements for which the reachability and intersection sets are same are the top-level element in the ISM hierarchy. After the identification of top level element, it is separated out from the other elements and the process continues for next level of elements. Reachability set, antecedent set, intersection set along with different level for elements have been shown below in table 1 .

Table 1: Iteration I

\begin{tabular}{|c|c|c|c|c|}
\hline $\begin{array}{l}\text { S. } \\
\text { No. }\end{array}$ & $\begin{array}{l}\text { Reachability } \\
\text { set }\end{array}$ & Antecedent set & $\begin{array}{l}\text { Intersectio } \\
\text { n set }\end{array}$ & Level \\
\hline 1. & 2,3 & $\begin{array}{l}1,2,3,4,5,6,7,8, \\
9,10,11,12,13,1 \\
4\end{array}$ & 2,3 & \multirow{5}{*}{ I } \\
\hline 2. & $\begin{array}{l}2,3,5,6,7,8,9,1 \\
2,13 \\
14\end{array}$ & $\begin{array}{l}1,4,5,6,7,8,9,10 \\
11,12,13,14\end{array}$ & $\begin{array}{l}5,6,7,8,9, \\
12,13,14\end{array}$ & \\
\hline 3. & $\begin{array}{l}1,2,3,5,6,7,8,9, \\
12,13,14\end{array}$ & $\begin{array}{l}1,4,5,6,7,8,9,10 \\
, 11,12,14\end{array}$ & $\begin{array}{l}1,5,6,7,8,9, \\
14\end{array}$ & \\
\hline 4. & $\begin{array}{l}1,2,3,5,6,7,8,9, \\
10,11,13,14\end{array}$ & $\begin{array}{l}1,4,5,6,7,9,10,1 \\
1,14\end{array}$ & $\begin{array}{l}1,5,6,7,9,1 \\
0,11,14\end{array}$ & \\
\hline 5. & $\begin{array}{l}1,2,3,4,5,6,7,8 \\
9,10,11,13,14\end{array}$ & $4,5,14$ & $4,5,14$ & \\
\hline
\end{tabular}

Table 2: Iteration II

\begin{tabular}{|c|c|c|c|c|}
\hline $\begin{array}{l}\text { S. } \\
\text { No. }\end{array}$ & $\begin{array}{l}\text { Reachability } \\
\text { set }\end{array}$ & Antecedent set & $\begin{array}{l}\text { Intersectio } \\
\text { n set }\end{array}$ & Level \\
\hline 2. & $\begin{array}{l}5,6,7,8,9,12, \\
13, \\
14\end{array}$ & $\begin{array}{l}1,4,5,6,7,8,9,10,1 \\
1,12,13,14\end{array}$ & $\begin{array}{l}5,6,7,8,9 \\
12,13,14\end{array}$ & \multirow{4}{*}{ II } \\
\hline 3. & $\begin{array}{l}1,5,6,7,8,9, \\
12,13,14\end{array}$ & $\begin{array}{l}1,4,5,6,7,8,9,10,1 \\
1,12,14\end{array}$ & $\begin{array}{l}1,5,6,7,8,9, \\
14\end{array}$ & \\
\hline 4. & $\begin{array}{l}1,5,6,7,8,9,1 \\
0,11,13,14\end{array}$ & $\begin{array}{l}1,4,5,6,7,9,10,11, \\
14\end{array}$ & $\begin{array}{l}1,5,6,7,9 \\
10,11,14\end{array}$ & \\
\hline 5. & $\begin{array}{l}1,4,5,6,7,8,9, \\
10,11, \\
13,14\end{array}$ & $4,5,14$ & $4,5,14$ & \\
\hline
\end{tabular}

Table 3: Iteration III

\begin{tabular}{|l|l|l|l|l|}
\hline $\begin{array}{l}\text { S. } \\
\text { No. }\end{array}$ & $\begin{array}{l}\text { Reachability } \\
\text { set }\end{array}$ & Antecedent set & $\begin{array}{l}\text { Intersectio } \\
\text { n set }\end{array}$ & Level \\
\hline 3. & 1 & 1,4 & 1 & \multirow{2}{*}{ III } \\
\hline 4. & $\mathbf{1 , 1 0 , 1 1}$ & $1,4,10,11$ & $1,10,11$ & \\
\hline 5. & $1,4,10$ & 4 & 4 & \\
\hline
\end{tabular}

Table 4: Iteration IV

\begin{tabular}{|l|l|l|l|l|}
\hline $\begin{array}{l}\text { S. } \\
\text { No. }\end{array}$ & $\begin{array}{l}\text { Reachability } \\
\text { set }\end{array}$ & Antecedent set & $\begin{array}{l}\text { Intersectio } \\
\text { n set }\end{array}$ & $\begin{array}{l}\text { Lev } \\
\text { el }\end{array}$ \\
\hline 5. & 4 & 4 & 4 & IV \\
\hline
\end{tabular}

\subsection{Dependence Power- Driving Power Diagram}

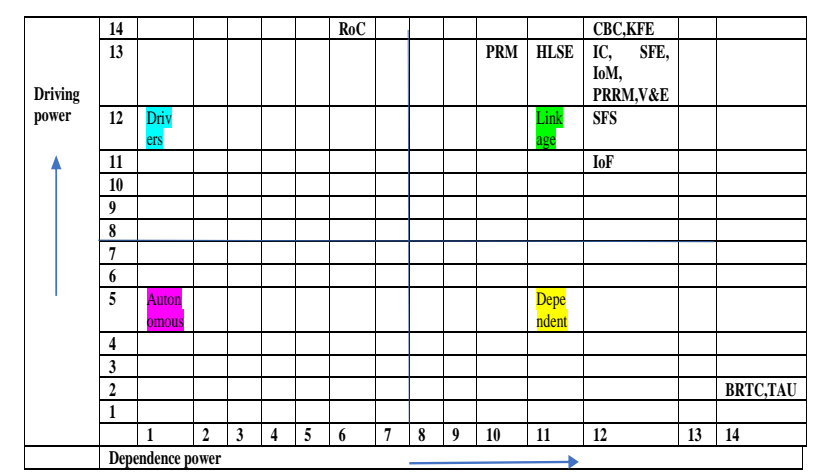

4.5 ISM Diagraph for the hierarchical relationship amongst the governing criteria [success factors] amongst the familial businesses 


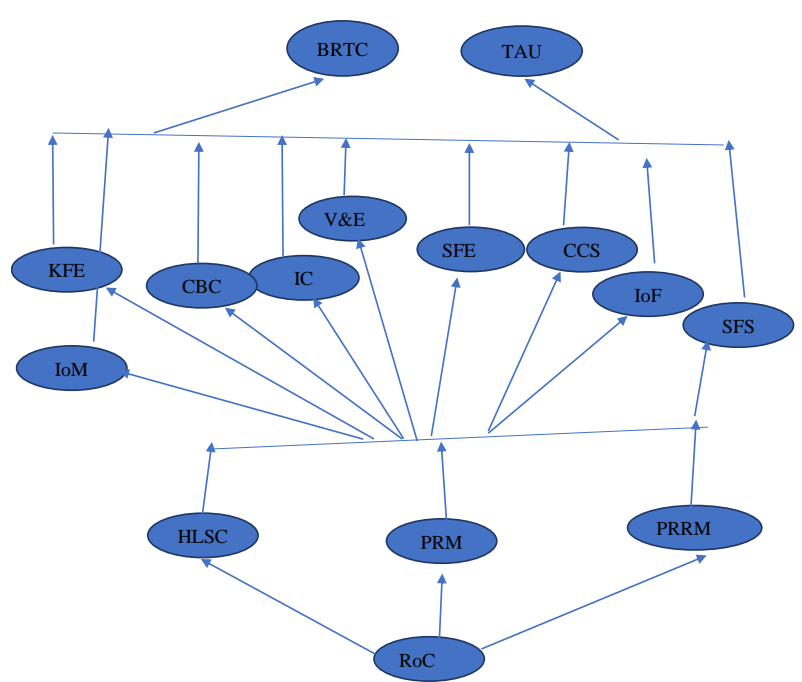

\section{CONCLUSIONS}

Present research explores the various success factors as well as challenges behind the running of family businesses in countries like India. thereafter, it tries to explore the inter-relationships amongst them using ism methodology . the research could be further extended to include decision making techniques such s structural equation modelling or TISM

\section{ACKNOWLEDGEMENTS}

Co-author Remica Aggarwal extend her sincere thanks to Prof. S.P. Singh, DMS, IIT Delhi for disseminating knowledge about ISM Methodology .

\section{REFERENCES}

[1] Dyer W. G., Handler W. C. 1994. Entrepreneurship and family business: exploring the connections. Entrepreneurship Theory Pract. 19, 71-83. $10.1177 / 104225879401900105$.

[2] Audretsch D. B., Belitski M., Desai S. 2015. Entrepreneurship and economic development in cities. Ann. Reg. Sci. 55, 33-60. 10.1007/s00168-0150685-x .

[3] Acs Z. J., Varga A. (2005). Entrepreneurship, agglomeration and technological change. Small Bus. Econo. 24, 323-334. 10.1007/s11187-005-1998-4

[4] Blanco-González A., Díez-Martín F., Prado-Román A. (2015). Entrepreneurship, global competitiveness and legitimacy, in New Challenges in Entrepreneurship and Finance: Examining the Prospects for Sustainable Business Development, Performance, Innovation, and Economic Growth, eds Peris-Ortiz M., Sahut J. M. (Springer International Publishing), 57-69. 10.1007/9783-319-08888-4_4.

[5] Zhao X., Li H., Rauch A. (2012). Cross-country differences in entrepreneurial activity: the role of cultural practice and national wealth. Front. Bus. Res. China 6, 447-474. 10.3868/s070-001-012-0021-0 .

[6] Rasul O., Bekun F. V., Akadiri S. S. (2017). The impact of self-efficacy on international student entrepreneur intention. Int. Rev. Manag. Mark. 7, 169-174.

[7] Arrighetti A., Caricati L., Landini F., Monacelli N. 2012. Entrepreneurial intention in the time of crisis: a field study. Int. J. Entrep. Behav. Res. 22, 835-859. 10.1108/IJEBR-12-2015-0326

[8] Kor Y. Y., Mahoney J. T., Michael S. C. (2007). Resources, capabilities and entrepreneurial

[9] Liñán F., Santos F. J., Fernández J. (2011). The influence of perceptions on potential entrepreneurs. Int Entrepreneurship Manage. J. 7, 373-390. 10.1007/s11365-011-0199-7.

[10] Biraglia A., Kadile V. (2017). The role of entrepreneurial passion and creativity in developing entrepreneurial intentions: insights from American homebrewers. J. Small Bus. Manag. 55, 170-188. 10.1111/jsbm.12242.

[11] McIntosh J. C., Islam S. (2010). Beyond the veil: the influence of Islam on female entrepreneurship in a conservative muslim context. Int. Manag. Rev. 6, 103109

[12] Anggadwita G., dwi Mulyaningsih H., Ramadani V. 2015. Women entrepreneurship in islamic perspective: driver for social change. Int. J. Bus. Global. 15, 389-404. 10.1504/IJBG.2015.071914

[13] Ahmed I., Nawaz M. M., Ramzan M. 2012. Do external factors influence students' entrepreneurial inclination? An evidence based approach. Actual Prob. Econ. 125, 51-58. 10.5772/36570

[14] Al-Harthi A. S. A. 2017. Understanding entrepreneurship through the experiences of Omani entrepreneurs: implications for entrepreneurship education. J. Develop. Entrepreneurship 22, $1-20$ $10.1142 / \mathrm{S} 1084946717500017$

[15] Bastian B. L., Sidani Y. M., El Amine Y. 2018. Women entrepreneurship in the Middle East and North Africa. Gender Manag. 33, 14-29. 10.1108/GM-072016-0141.

[16] Sieger P., Fueglistaller U., Zellweger T. (2016). Student Entrepreneurship 2016: Insights from 50 Countries. International report of the GUESSS Project 2016. http://www.guesssurvey.org/resources/PDF_InterR eports/GUESSS_2016_INT_Report_final5.pdf

[17] Zellweger T. (2017). Managing the Family Business: Theory and Practice. Cheltenham: Edward Elgar.

[18] Garcia P. R. J. M., Sharma P., De Massis A., Wright M., Scholes L. 2018. Perceived parental behaviors and nextgeneration engagement in family firms: a social cognitive perspective. Entrep. Theor. Prat. 43, 224-243. $10.1177 / 1042258718796087$

[19] Dawson A., Sharma P., Irving P. G., Marcus J., Chirico F. 2015. Predictors of latergeneration family perceptions. J. Manag. Stud. 44, 1187-1212. 10.1111/j.1467-6486.2007.00727.x

a. members' commitment to family enterprises. Entrep. Theor. Pract. 39, 545-569. 10.1111/etap.12052.

[20] Marshall et al. (2018) Marshall D., Dibrell C., Eddleston K. A. (2018). What keeps them going? Socio-cognitive entrepreneurial career continuance. Small Bus. Econ. 53, $1-16.10 .1007 / \mathrm{s} 11187-018-0055-\mathrm{Z}$

[21] Nordqvist M., Melin L. (2010). Entrepreneurial families and family firms. Entrep. Reg. Dev. 22, 211-239. 10.1080/08985621003726119. 
[22] .Chlosta S., Patzelt H., Klein S. B., Dormann C. 2012. Parental role models and the decision to become self-employed: the moderating effect of personality. Small Bus. Econ. 38, 121-138. 10.1007/s11187-010-9270-y.

[23] BarNir A., Watson W. E., Hutchins H. M. 2011. Mediation and moderated mediation in the relationship among role models, self-efficacy, entrepreneurial career intention, and gender. J. Appl. Soc. Psychol. 41, 270-297. 10.1111/j.15591816.2010.00713.x .

[24] Bosma N., Hessels J., Schutjens V., van Praag M., Verheul I. 2012. Entrepreneurship and role models. J. Econ. Psychol. 33, 410-424. 10.1016/j.joep.2011.03.004

[25] Neneh B. N. (2017). Family support and performance of women-owned enterprises: the mediating effect of family-to-work enrichment. J. Entrep. 26, 196-219. $10.1177 / 0971355717716762$.

[26] Nowinski W., Haddoud M. Y. (2019). The role of inspiring role models in enhancing entrepreneurial intention. J. Bus. Res. 96, 183-193. 10.1016/j.jbusres.2018.11.005.

[27] Denanyoh R., Adjei K., Nyemekye G. E. 2015. Factors that impact on entrepreneurial intention of tertiary students in Ghana. Int. J. Bus. Soc. Res. 5, 19-29.

[28] Laguía A., Moriano J. A., Gorgievski M. J. (2019). A psychosocial study of self-perceived creativity and entrepreneurial intentions in a sample of university students. Think. Skills Creat. 31, 44-57. 10.1016/j.tsc.2018.11.004

[29] Sahinidis A., Stavroulakis D., Kossieri E., Varelas S. (2019). Entrepreneurial intention determinants among female students. The influence of role models, parents occupation and perceived behavioral control on forming the desire to become a business owner, in Strategic Innovative Marketing and Tourism. Springer Proceedings in Business and Economics, eds Kavoura A., Kefallonitis E., Giovanis A. (Cham: Springer; ), 173178. 10.1007/978-3-030-12453-3_20.

[30] Logan J. (2014). An exploration of the challenges facing women starting business at fifty. Int. J. Gender Entrep. 6 , 83-96. 10.1108/IJGE-03-2013-0019 .

[31] Raghuvanshi J., Agrawal R., Ghosh P. K. (2017). Analysis of barriers to women entrepreneurship: the DEMATEL approach. J. Entrep. 26, 220-238. $10.1177 / 0971355717708848$.

[32] Pratik Mantri , https://www.egrowth.org/blog/five-realchallenges-faced-by-family-businesses-in-india

[33] https://economictimes.indiatimes.com/familybusinessfor um/insights/perks-and-problems-of-indian-familybusinesses/familybusinessforum_show/62527565.cms

[34] Warfield, J.N. 1974. Developing interconnection matrices in structural modelling, in the proceedings of IEEE Transactions on System, Man, and Cybernetics, SMC, 4 (1), 81-87. 